AUTHOR:

J.H. Van Wyk

CORRESPONDENCE TO:

J.H. (Amie) Van Wyk

DATES:

Published: 21 Aug 2018

HOW TO CITE THIS ARTICLE:

Van Wyk, J.H., 2018. An essay on what the reformation could not prevent

the identification of church and 'volk'. Three examples reconsidered. KOERS - Bulletin for Christian Scholarship,

83(1). Available at: https://doi.

org/10.19108/KOERS.83.1.2403

COPYRIGHT:

(c) 2018. The Author(s)

Published under the Creative Commons Attribution License.

\section{AN ESSAY ON WHAT THE REFORMATION COULD NOT PREVENT THE IDENTIFICATION OF CHURCH AND 'VOLK'. THREE EXAMPLES RECONSIDERED}

\author{
Summary \\ In this year of REFO 500 the author investigates the question why the Reformation with its \\ 'theology of sola Scriptura and solus Christus' could not prevent the successive identification \\ of church and 'volk' in history and why it could not prevent the fatal consequences this \\ identification had for the gospel message of reconciliation, the exemplary existence of the \\ church of Christ and the coming of the kingdom of God. Three examples serve as proof for \\ this statement: the attitude of the Anglican Church in England during the second Anglo-Boer \\ War (now called the South African War)(1899-1902); the Lutheran Church in Germany during the \\ Second World War (1939-1945) and the Reformed Churches in South Africa during the years of \\ apartheid (1948-1994). All three examples reveal an untenable identification of church and 'volk', \\ although in varying degrees. How could that happen?
}

Key words: Reformation, church and 'volk', Anglican Schurch, England, imperialism, Lutheran Church, Germany, Nazism, Reformed churches, South Africa, nationalism (apartheid)

\section{Introduction}

The Reformation of the sixteenth century is characterised by the well-known five 'solisms': only Christ (solus Christus), only grace (sola gratia), only faith (sola fide), only the Scriptures (sola Sriptura), glory only to God (soli Deo gloria). The focus is on Christ, on grace, on faith, on Scripture, on God. What is lacking is a perspective on the church and on the Spirit. But one would expect that with a concentration on Christ and on the Scripture, the view on the church and the Spirit would easily fall in place. And yet it did not happen.

Whilst Scripture is very clear on the unity of the church, led in all truth by the Spirit, we experience a disruption of the unity of the one church, dividing into different churches opposing one another and contradicting each other's confessions and decisions in many ways. Although there were minor divisions in the Early Church, the first division worth mentioning took place in the year 1054 when the Eastern and Western Churches separated from each other. The next great schism took place during the period of the Reformation in the sixteenth century when the Protestants and Roman Catholics were divided. Very soon the Protestants split up into Lutherans, Reformed ('Calvinists') and Anglicans. The Reformed church soon divided into many 'true' churches, the one trying to surpass and outclass the other as 'the true church of Christ'. Whilst Augustine in the fifth century did his best to unify the 'Donatist' and catholic church in North-Africa (Van Wyk, 2015:272-276) and Calvin was willing to cross ten seas to promote the unity of the church (Van Wyk, 2015:258-268), it seems that nowadays Christians do not have the slightest problem to disunite and to start a new church - in radical contradiction with the teaching of Scripture and the prayer of Christ (Van Wyk, 2015;241-257). How is that possible?

How is it possible that the church of Christ, guided by the light of the Word and the Spirit of God, nowadays with a good conscience could so easily contradict the prayer of Christ 
for the unity of his followers "so that the world will believe that you (the Father) sent me" (John $17: 21$ )? How can the world believe a message of reconciliation if churches themselves live in disarray and contradict each other's synodical decisions? Shouldn't we conclude that the way in which reformed Christians accept and participate in church schisms, shows that they are acting in a totally unbiblical way in this regard, and also very un-Christ-ian?

How was it possible that Protestant churches - Anglicans, Lutherans and Reformed - could identify more with their 'volk' than with Jesus Christ, their Lord? How was is possible that the Reformation could not prevent the disunity of the church and the identification of church and 'volk'? The Reformation emphasised the sola Scriptura, the solus Christus and we may add the solus Spiritus, and yet failed to avoid the division and 'culturalisation' of the church of Christ. What should be done to avoid this falsification of the church?

This article aims to investigate the relationship among three church denominations and the 'volk' during three times of crisis which took place in the twentieth century. The first deals with the stance of the Anglican Church in England (in South Africa called Church of the Province of Southern Africa) during the Anglo-Boer War (1899-1902), now called the South African War. The second refers to the attitude of the Lutheran Church in Germany before, during and after World War Two (1939-1945). The third deals with the standpoint of the Afrikaans churches in South Africa during the years of apartheid (1948-1994) - although in varying nuances.

What happened that - in all three cases - the church of Jesus Christ, whether Anglican, Lutheran or Reformed, did not foresee the dangers of a too close relationship between church and 'volk' and was carried along a road which undermined and blurred the character of the church of Christ and the essence of the gospel of grace? Why were Christians overruled by political ideologies of nationalism and imperialism instead of guided by Christian convictions of love, justice, freedom and reconciliation? Why did the church of Jesus Christ in times of crisis almost always identify with the values of the 'volk' instead of that of the kingdom of God?

The three examples that we are going to investigate give a vivid illustration of British imperialism, German Nazism and Afrikaner apartheid and of churches which identified more with the 'volk' than with the gospel of Christ.

Anglican churches in England and South Africa supported the British policy of nationalism and imperialism during ABW2 without reservation and criticism. Lutheran churches in Germany supported German nationalism and Nazism without criticism during WW2. Afrikaans churches supported Afrikaner nationalism during the years of apartheid without criticism. Although all three 'denominations' developed from the Reformation, they all failed to resist the dangers of a 'volkskerk'.

What we have in mind, is not an investigation into the relationship between church and state (see Van der Kooi \& Van den Brink 408-474, 568-576), but the focus is more on the relation between church and 'volk' and the problem of identification of the one with the other.

\section{The Anglican Church And The Anglo Boer War 2 (1899- 1902)}

Our first example is that of the Anglican Church in England (but it also includes the Church of the Province of Southern Africa).

There were many reasons for the origin of the war that Britain fought against the two republics in South Africa, namely De Zuid-Afrikaansche Republiek (ZAR) (later called 
Transvaal) and the Orange Free State, but from any point of view it was an aggressive, fanatic and imperialist war which contradicted many of the characteristics of a just war that was rooted in Christian ethics. From a theological perspective the question is raised: why was the church of Christ, in this case the Anglican Church, so silent before, during and after the war?

A strong feeling of British imperialism - or aggressive nationalism - was the reason for the Unionist (Conservative) Party in 1895 to rule Britain (Pretorius 1998:36). As far as church association of the soldiers in Britain is concerned, the following statistics of the Regular Army give us a picture: Anglican 68.6\%, Roman Catholic 17.9\%, Presbyterian 7.5\%, Wesleyan 5.3\% (Pretorius 1998:37).

It was not just an ordinary war, because during the last two years (of guerrilla warfare) the war took a shape that was totally monstrous, brutal and barbarous. "Farm animals such as sheep, cattle, pigs and chickens were slaughtered. Farmlands and the veld were set alight, while in some cases entire towns were destroyed" (Brits, 2016:37).

Yes, there was opposition in Britain against the war, because three weeks after the outbreak of the war the South African Conciliation Committee was launched in England by liberal Britons who opposed the war under the leadership of Lord Courtney (Brits, 2016:36). But the Church kept silent - was it a matter of ignorance or apathy?

When the brave Englishwoman, Emily Hobhouse, appeared on the scene she tried her utmost to make the British people aware of the atrocities of the war, especially in the concentration camps. She tried to make contact with British leaders like Milner and Kitchener to change their minds - in vain. She visited many camps in South Africa and saw the devastating effect of desperate conditions in the camps.

Near Warrenton Emily witnessed the following scene next to the railway: "The faces of the women and children were grimaces of pain as a result of exposure, hunger and exhaustion. The scene represented the cruelty and horror of war in its clearest form" (Brits, 2016:66).

During the war 34000 Afrikaner people lost their lives, of whom 28000 were women and children in concentration camps, as well as 20000 black people. ${ }^{1}$ Many church buildings and about 30000 houses $^{2}$ were destroyed in the Orange Free State and the ZAR, and many congregations scattered. Today it would be described as "a crime against humanity", even "a crime against Christianity" - Christians fighting against other Christians for a pot of gold! ${ }^{3}$

In this regard De Gruchy (1998:7-8) refers to the "atrocities of the concentration camps" and that it was the policy of the British government at that time to destroy the Afrikaner culture. He continues: "Tragically, the role of the English-speaking churches in all this was entirely jingoistic - not only was there no criticism of the imperial war effort, there was total support of it." ${ }^{\prime \prime}$

$1 \quad$ See Bossenbroek, 2012: 435; B. Nasson in Giliomee \& Mbenga, 2007:220; Smurthwaite, 1999:148-151. Pretorius (1998:81) refers to 27927 whites and 14154 blacks who died in concentration camps. See in this regard also the novels of Baker (1998:253-260,266-275,281-291) and Van Rooyen (2000:565-574) The books of Packenham (1999) and Wessels and Raath (2012) give a vivid exposition of the crimes that took place during the ABW2

$2 \quad$ See Pretorius 1998:56.

3 Although not meant as books on the history of the ABW2, the following novels recaptured the material of that war: Baker, Groot duiwels dood (1998); Van Rooyen, Vuur op die horison (2000); Winterbach, Niggie (2002); Du Plessis, Fees van die ongenooides (2008).

4 Archbishop Desmond Tutu is of the opinion that the bitterness between Afrikaans- and English-speaking South Africans could have been avoided if there had been a process of a truth and reconciliation commission a century earlier (see Allen, 2006:352). 
Up to now, there has been no explicit articulation of remorse from the side of the Englishspeaking churches in England or in South Africa - a fact which was experienced with regret and disappointment by Afrikaans-speaking Christians during the years of apartheid when the English-speaking churches (correctly) criticised the system of apartheid.

The ABW2 radically changed the South African scene. It stimulated Afrikaner patriotism and nationalism to the utmost. It was, in essence, a conflict between Afrikaner nationalism and British imperialism.

What is intriguing during these years of disaster is that there was no official response from the side of the Anglican Church in England and in South Africa and that it was an individual Anglican, Emily Hobhouse, who stood up against British imperialism and chose and defended the side of the underdog because of a sense of justice. The Anglican Church, however, never released any declaration of sympathy about what happened during this horrific war.

\section{The Lutheran Church and the Second World War (WW2) (1939-1945)}

The situation before, during and after WW2 differed from that of the ABW2 but a basic trend is found in both of them, namely an ideology of nationalism and race superiority. The focus in Germany, however, was also coloured by an approach of anti-Semitism. While the Anglican Church kept silent, the Churches in Germany, i.c. the Lutheran Church, eagerly followed and supported the German leaders. ${ }^{5}$

Already before the outbreak of the war, the Confessing Church ("Bekennende Kirche") in 1934 released the famous Declaration of Barmen, with the reformed theologian Karl Barth as main writer (Busch 1976:258). This Declaration was published as a protest against Nazism and "German Christianity". Barth blamed Luther who opened the way for Hitler to compromise the church because of his (Luther's) two-kingdom theory. Barth had to leave Germany because he refused to sign unconditionally the oath of loyalty to Hitler (Busch, 1976:268; Van Itterzon \& Nauta, 1967:113). ${ }^{6}$ During the war many other theologians opposed the Nazism of Hitler, such as the Lutherans Martin Niemöller and Dietrich Bonhoeffer, the last paid with his life for his resistance (Van Wyk, 2001:153-187). ${ }^{7}$ Bonhoeffer was even prepared to join a small group of resistance fighters to eliminate Hitler. In this regard he used the following metaphor: When a drunken driver speeds over the Kurfürsterdamm, it is not the first and most important task of a minister of religion to bury the victims and to comfort the family; it is more important to pull out the drunkard behind the steering wheel. Bonhoeffer also criticised the two-kingdom concept of Luther (see Van Wyk, 1991:216-220; 2001:177; 174-175).

The "Deutsche Christen"-movement followed a "volk"-theology: God revealed Himself in the history of the German people who received a special task (Van Itterzon \& Nauta, 1967:111). It was a kind of 'culture Protestantism' and optimism where the differences between church and 'volk' almost disappeared and the characteristics of church and 'volk' were almost identical.

$5 \quad$ Also the Roman Catholic Church was guilty (see Janson, 1967:43).

6 See Busch (1976:248-261) on Barth and the church struggle in Germany. Authors who gave a shocking description of the murder camps of the Germans are Overduin (n.d.) (Dachau) and Améry (1980)(Auschwitz).

$7 \quad$ Also Adolf Schlatter (who died in 1938)(see Neuer 1988:162-176) was critical about the rising Nazi-movement and the way in which the Lutheran Church and theologians supported the German nation. Schlatter also wrote a book (against the advice of Kittel) against the role of the "Deutsche Christen". 
Researchers like Ericksen (1986) and Forstman (1992) tried to clarify how and why leading theologians in Germany developed a theology in which national sympathies played a decisive role not only in politics but also in theology and church, where national aspirations were not just the context but the actual content of theology. It resulted in a Nazification of theology. Names that were mentioned in this regard, were Gerhard Kittel, Paul Althaus and especially Emanuel Hirsch (see Erickson, 1986), to which we could add the name of Friedrich Gogarten. For Althaus and Hirsch volk and race were creational orders (Wind, 1991:51) and both released a strong nationalistic declaration in 1931 (Wind, 1991:43, 51). In the 'theology of creation orders' the orders became over-riding and church and theology were forced to focus on their 'own subjects', namely the Bible, faith and eternal life. The church lost its task of prophetic witness in society, here and now, because - according to the two- kingdom theory - society is the sphere where the government rules. The next step is to idolise the 'volk', to develop a 'volks religion' and a 'volkskerk' and to demonise all other 'volke'.

It seems that theologians with a more Christocentric approach in theology, like Barth and Bonhoeffer, were more cautious about the temptations of National Socialism and Nazism. It also seems that theologians who took a more Christological approach in theology, who stressed the gospel, love and grace more than law, obedience, authority and orders of creation (like Barth and Bonhoeffer), tended to be more immune to the dangers of Hitler's racism (see Ericksen, 1986:25).

What is worthy of consideration is that after the war the "Evangelische Kirche in Deutschland" in 1945 released a confession of guilt in Stuttgart in which they declared (in general terms) that the German nation as a whole was guilty of what happened during the war (Jansen, 1983:382-384). But this confession was criticised as 'too little too late'.

In the years 1939-1945 the churches and theologians in Germany were not totally silent, but in general they are criticised for creating fertile soil for the development of a 'volkskerk' and a 'volks theology' which made it very easy for a dictator like Hitler to plunge Western Europe - and the world - into a war with far-reaching consequences - 60 million people died during this war.

Why were theologians and churches influenced by an ideology to such an extent that they failed - to a large degree - to help prevent a catastrophe in world history? Why did they fail with the Bible in their hands and the gospel of Jesus Christ in their hearts?

\section{Reformed Churches in South Africa and the policy of apartheid (1948-1994)}

Whilst almost the whole world sympathised with South Africa during the years of the ABW2, the situation radically changed during the years 1948-1990 when South Africa was regarded as the polecat of the world because of the policy of apartheid. This policy was regarded and rejected by the outside world and international church communities as discriminatory and cruel and in radical conflict with the gospel of Jesus Christ. The striving for national freedom amongst the Afrikaner people, that was lost during the ABW2, rapidly evolved into imperialism where minority rule was the order of the day. A whole series of discriminatory laws against the black majority people were launched, differing from where they were allowed to stay, work, move, sit, to whom they might marry. How could this happen, and happen with the support of Afrikaans churches and Afrikaans theologians? How could it happen that Afrikaans churches and theologians supported an ideology that was later defined as a sin and the theological justification of it a heresy? ${ }^{8}$ 
There are more names that could be mentioned here, but I am not going to refer to all of them. From the side of the NGK (DRC) there were the New Testament scholar EP Groenewald and the dogmatists F.J.M. Potgieter and A.B. du Preez. From the Hervormde Kerk (NHKA) there were the missionary H.P. Wolmarans and the church historian A.D. Pont. From the Gereformeerde Kerke in Suid-Afrika (GKSA) ('Dopperkerk') the names of the well-known Bible translater J.D. du Toit (Totius) and the philosopher H.G. Stoker could be mentioned. Although he did not live during the period of institutionalised apartheid, the name of the state president of the ZAR, Paul Kruger, should also be mentioned in this regard.

It is remarkable that it was a former (DRC) minister of religion who became the first prime minister in South Africa with an apartheid agenda in 1948, namely D.F. Malan. He was typified by Thom as "the founder of the apartheid policy in South Africa" (Thom 1980:23,271) - although many others would claim this characterisation. Malan used the slogan: "Believe in your God! Believe in your volk! Believe in yourself!" (Malan 1959:239), but he found a vigorous opponent in L.J. du Plessis of Potchefstroom who argued that he could only believe in God through Jesus Christ (see Van Wyk, 1993:50-51).

Because I am a member of the Gereformeerde Kerke in Suid-Afrika (GKSA), I am going to focus on the views of Kruger, Totius and Stoker. ${ }^{9}$

It is intriguing to discover how Paul Kruger, especially in his telegrams which he sent to Boer leaders during the ABW2, could identify the Afrikanervolk with the church of Christ (see Bergh 2017:497-581). In most of his telegrams he would inspire the Boer fighters to keep going with a reference to the words of the Lord that those who want to save his own life will lose it, but whoever loses his life (for the truth) will find it (Matt 16:25)(see Bergh, 2017:504,505). Other Scriptural references that functioned in this regard, are Psalms 27, 83, $108,115,118$. The war of the British against the Boers is typified as "an onslaught of the devil against Christ and his church" (Bergh, 2017:514). Well-meant advice but exegetically totally out of context. Church and 'volk' were incorrectly identified.

Totius' views on apartheid are basically found in his presentation in 1944 in Bloemfontein during a 'volkskongres', namely "The religious foundation of our race policy" (Du Toit, 1977:330-343). Totius took his point of departure in the doctrine of God: God is the great Separator, at creation, at the tower of Babel and in Israel. Totius also emphasises the providence and the council of God who created different nations (Acts 17:26). The Bible teaches a pluriformity of nations; the "higher unity" in Christ is spiritual in character. Although we can be thankful that slavery has been abandoned, guardianship over natives is permanent.

What is remarkable in this approach of Totius is his undervaluation of Christology. There is no effort from his side to investigate the question whether, and in what sense, the race dilemma should be examined from the perspective of Christology and what the consequences of this might be. In another publication from 1941 on the Bible as the Word of God, Totius correctly argued that the Bible contains the revelation of God and that it unfolds God's plan of redemption for us "as centralised in Jesus Christ" (Du Toit 1941:42). Nothing of this centralism is heard when Totius developed his theology of politics. Why did this happen? Did the ideology of apartheid play a dazzling role in his approach? Keep in mind that Totius personally experienced the ABW2 for nine months as a 'veldprediker' (minister in the field) and had seen some of the atrocities of that war (d'Assonville, 1977:2232).

the ideology of apartheid? Moltmann (2008:235) said that he found apartheid so "obnoxious" that on his flight back home "I resolved never to go back until the system had disappeared." He revisited South Africa in 2017 and welcomed the new South Africa. I told him then that it was a Potchefstromer (FW de Klerk) who initiated the end of apartheid. 
I have also mentioned the name of the influential philosopher from Potchefstroom, namely H.G. Stoker. Although he rejected (German) national socialism, he also argued in favour of separate development, although in a nuanced form. He also minimised the relevance and implications of the message of Christ (Christology) for social ethics and could not free himself fully from the apartheid ideology. I wrote an essay on Stoker with the subtle title: "Liberal conservatism?" (Van Wyk, 2001:188-213). Was his Christian approach to philosophy also preconditioned and determined by a 'volks' ideology, the 'volk' being one of the orders of creation?

While the Afrikaans churches, with different nuances, favoured, propagated and defended the policy of apartheid, later called separate development, there were theologians who opposed that policy, as had been the case in Germany.

There were 'connected critics' (from the inner group) and 'committed critics')(rom the outside group). In the NGK the names of W.D. Jonker, D.J. Bosch and J.A. Heyns (in his last phase) were from the inner group, while Beyers Naudé and JA Durand (both belonged to the NGKA, Naudé in a latter phase) were from the outside group and all of them, although in different ways, opposed and attacked apartheid as a political and ecclesiological error. This resistance reached a climax in the Belhar Confession of 1986, drafted by D.J. Smit and J.A. Durand, and adopted by the NG Mission Church. In 1990 a confession of guilt was expressed by W.D. Jonker. In the GKSA theologians and philosophers like J.A. van Rooy, J.M. Vorster, B.J. van der Walt, Ponti Venter and myself took a critical stance as far as apartheid was concerned. In 1997 a confession of guilt was published by four Potchefstromers (Alwyn du Plessis, Bennie van der Walt, Amie van Wyk and Ponti Venter)(see Van Wyk, 2001:24-51). ${ }^{10}$

The question to be answered is: how could it happen that theologians and churches supported an ideology and a political system which connected church and 'volk' so closely that it contradicted the essence of the gospel of Christ?

As far as the GKSA as a church community is concerned, a movement from 'separate development' to church unity can be observed. W.J. Snyman, professor in New Testament theology in Potchefstroom, assisted the church to move away from a volkskerk' to a 'volkerekerk' as he called it (see Van Wyk 1985). ${ }^{11}$ This implied that different national synods (of the different 'volke') should meet in a united general synod. He also advised many GKSA synods to decide that church disunity is a sin and that unity should be pursued earnestly - as a calling from God. This led to a meeting of the first general synod in 1965 in Potchefstroom, but it came to an end in 1992 because the so-called 'younger' churches argued that even this model of 'volkerekerk' was too much typified by a 'volkskerk' idea. The general synod was re-established in 2006 after separate black and white classes were united in regional synods. Regional and general synods were now fully multicultural - the first of the Afrikaans churches to do so.

It is worth mentioning that it was a member of the GKSA, F.W. de Klerk, who released Nelson Mandela and other political prisoners in 1990, who initiated a new political dispensation in South Africa.

I interrupt myself and focus for a moment on the fact that while the Afrikaans churches in the beginning supported the ideology of apartheid and struggled for a long time to detach

10 In 1983193 ministers of religion of the Afrikaans churches released a document in which they unambiguously supported apartheid and on which I critically responded (see Van Wyk 1991:311-322)

11 In 1986 I sent a copy of my booklet on Snyman to H.N. Ridderbos, professor in New Testament studies in the Netherlands. He replied in a letter in which he appreciated the stance of Snyman but added (my translation): "After many visits to South Africa I could never understand why so many good people could support such a "bad" politics in my view" (Letter 13th January 1986). 
themselves from this ideology, many announcements and declarations from the side of the English-speaking churches were released in the twentieth century. I mention the following:

The Cottes/oe Declaration of 1960, organised by the WCC

A Message to the People of South Africa in 1968, released by the South African Council of Churches

The Kairos Document: A Challenge to the Church: A Theological Comment of the Political Crisis in South Africa in 1985/1986 by Kairos Theologians ${ }^{12}$

Evangelical Witness in South Africa in 1986 by the Charismatic and Pentecostal churches

The Road to Damascus in 1989 by Third World Christians

It is significant that the Afrikaans churches and Christians in general viewed these documents with a certain kind of scepticism, not because these documents did not contain much truth, but because the English-speaking churches never released a word of criticism or repentance about the atrocities that took place during the ABW2. This negligence gave these documents a kind of double morality: I criticise you when your 'volk' (or church) is doing wrong, but I forget or neglect the wrongs of my own 'volk' (church). It is so difficult, even for the church of Christ, always to be self-critical when criticism of others is launched.

\section{How could it happen (over and over again)?}

The question arises: Why are churches and Christians overruled by a political ideology of nationalism instead of seeking the kingdom of God and sticking to Christian convictions of love, peace, justice, freedom and reconciliation (13 $^{13}$

In my diagnoses, I'll reflect on the road I myself have travelled from someone who welcomed the Republic of South Africa in 1961 to someone who rejected apartheid as an immoral policy in the 1970s.

There are many reasons for a church to develop into a 'volkskerk' which denies the attributes and the marks of a true church of Christ. I'll mention some of them. ${ }^{14}$

The first reason relates to the interpretation of the Bible. One of the great problems is a prejudiced and fundamentalist understanding of the Biblical text (see Van Wyk 2015:2730; Vorster 2008). The interpreter starts off with the prejudice that God created 'volke' and therefore a 'volk' is a creation order which should be protected at any price. The next step is to find Biblical support for this standpoint, which is easily found in the story of Babel (Gen 11:8; see Acts 10:26 and Rev 21:3). What is problematic in this interpretation is a total lack of a Christological understanding of every Biblical text (Luke 24:44; Heb 1:1-2). No part in Scripture should be understood without putting Christ in the centre of that interpretation. To this I may add the supreme importance of the kingdom of God, which should be the primary focus of every church and every Christian (Matt 6:33).

It is of the utmost importance to emphasise a Christological interpretation of a Biblical text.

12 See Van der Walt (ed.) 1987. My article in this booklet deals with the question of resistance (1987:9-18).

13 The South African historian C.W. de Kiewiet asked himself the question how was it possible that the Afrikaners, amongst whom there were so many sincere and sympathetic Christians, could live with a policy which brought so much harm to people with the same faith, language and culture (namely the coloured people in South Africa (reference in Giliomee, 2016:226).

14 See also my (brief) article "How could all this happen?" in Van Wyk, 1998:196-199. 
As Calvin puts it: Jesus Christ is the scope and sum of the Word of God; the revelation of God attains its finality, culmination and conclusion in Christ (Calvijn, Inst. 4.8.7). Unfortunately, during the period after the Reformation, scholastic intellectualism and orthodoxy appeared on the scene, which to a great extent undermined the splendour of the Reformation and felt back into a certain kind of fundamentalism and an atomistic use of biblical texts (see Malan, 1981; Schulze, 1978:323-239). ${ }^{15}$ However, in the twentieth century Bavinck, the well-known Reformed theologian in the Netherlands, recaptured the stance of the Reformation when he argued that the revelation of God is "predominant[ly] a revelation of God in Christ" (Bavinck 1928:354); Christ is the "content" and "centre" of it (Bavinck 1928:354), the "culmination" and "conclusion" (Bavinck, 1928: 319,355). However, after the Reformation, Protestant and Reformed theology deviated in many ways from this fundamental Christological approach, especially in ecclesiology, which paved the way for an easy identification of church and 'volk'.

It is remarkable to discover that those theologians, like Barth and Bonhoeffer, who put Christology and a Christological interpretation of Scriptures in the centre of their theological thinking, were the most alert to the dangers of a 'volksteologie' and a 'volkskerk'.

A second reason to be mentioned is the role of influential theologians. Looking back at the story told in parts $2-4$, it is clear that leading theologians played a very influential role in the churches. But these theologians were preconditioned by a 'volkstheology' which blinded their interpretation of Scripture and which ended up with an identification of church and 'volk' which totally ignored the ecumenical character and the unity of the church of Christ. This shows us that believers should never blindly follow any theologian, how important he/ she may be, but should always be alert, putting all ideas to test, keeping what is good and avoiding every kind of evil ( 1 Thess. 5:21-22). ${ }^{16}$

A third reason which must be considered relates to the role of the Church in situations of political and social turmoil. ${ }^{17}$ It is true that the Early Church formed a minority in society and was often severely persecuted, but in the twentieth century the church of Christ rediscovered her prophetic role in society, especially since the turbulent years during WW2 and the years of apartheid in South Africa. As had been the case with the Old Testament prophets, the church of the New Testament has an indispensable task to preach a message which include truth, peace, justice, freedom and human dignity. A church community in a certain country always needs the assistance of the world wide ecumenical church to break the chains of a 'volkskerk' and in this regard the Reformed Ecumenical Synod/Council and the World Alliance of Reformed Churches played a very important role. ${ }^{18}$ For instance, in 1991 the GKSA accepted the following recommendation of the Reformed Ecumenical Synod: "the ideology of apartheid is a sin and the theological justification of it a heresy" (Acta GKSA 1991:160). If we do want to understand how broad and long, how high and deep, the love of Christ is, we should do so together with all God's people (Eph 3:18). In other words, understanding the message of God is an ecumenical task which should be undertaken by the universal church. This does not disqualify the clarity (claritas) of the Scripture for the

15 When one analyses the conclusions of the doctoral thesis of Van der Walt (1989), in which he deals with the synodical decisions of the GKSA on ethical matters, it clearly shows how many of these decisions are fundamentalist in character (see also the examples given by Van Wyk, 1989:56-59).

16 See my critical remarks on the testimony of the 193 ministers who supported apartheid in 1983 (Van Wyk, 1991:311-322).

17 It is interesting to note that in recent studies on the New Testament (see Joubert, 2012; Van der Watt \& Tolmie, 2014; König, 2014; König, 2017) almost no reference appears to the notion church and 'volk'.

18 In 1982 the WARC suspended the relationship of the NGK and NHKA, but later restored the relationship when both church communities rejected apartheid. 
individual reader, which was promoted by the Reformation, but this clarity refers in the first place to the central message of the Bible, that is the message of salvation. The Holy Scriptures fully contain the will of God "and whatsoever man ought to believe unto salvation is sufficiently taught therein" (Belgic Confession art 7). There are, however, other parts in Scripture which are not so easy to understand - as Peter already knew, 2 Peter 3:16 - where we need not only the illumination of the Holy Spirit but also the insight of fellow Christians.

It is imperative that churches should not be led astray by the two-kingdom theory of Luther. While it is important to distinguish between church and 'volk', this does not mean that the church should keep silent in cases of absolutized nationalism. The church always has got a prophetic witness in society to fulfil. The church should never take a stance of apathy, ignorance, negligence and incompetence when a prophetic witness in society is expected and necessary.

Churches should also differentiate, on the other hand, between identification or acculturation with the 'volk', which is always wrong because it eliminates the character of the church as the body of Christ, and, on the other hand, responsible enculturation, which is a correct option, where a church takes a responsible shape in a specific culture without destroying its essence as church of Christ (see Bosch, 1991:447-457; Banze, 2015:259-276; Verster, 2017:772-783).

A fourth reason to mention is the fact that the importance of ethics must be rediscovered, especially social ethics. The ethics of the New Testament, written in a context where Christians were a minority, is very much focussed on the individual. During the twentieth century greater emphasis is laid on the fact that individuals live within economic, political and social structures which have an immense effect on their lives (see Moltmann, 2012; Vorster, 2014). Nowadays radical capitalism and radical socialism are being challenged by a system of social democracy. In a plural society a political system of a plural democracy is also in many ways a better option than a liberal democracy, because it meaningfully relates the notions of unity and diversity and avoids the danger of disunity and uniformity. The implication of this approach means that a peaceful society in South Africa can only be created when a system of majority rule is complemented by minority rights. The apartheid system, being a dictatorship of the minority, should not be replaced by a dictatorship of the majority - a trend which becomes more and more evident today.

A fifth reason to refer to is the danger of power-seeking politicians (dictators) who must be observed, revealed and opposed by individual Christians and by the church itself. During the years of the ABW2, WW2 and apartheid it was quite clear that power-seeking politicians played a devastating dictatorship role and succeeded in capturing the church for political purposes and nationalistic ideals. We experience this tendency very clearly today in South Africa in the approach of president Jacob Zuma who argues that "the ANC will govern until Jesus comes" and that "God is on the side of the ANC and we cannot lose (the election of 2019)" (Botha, 2017:18). ${ }^{19}$ The recent worldwide growth in right-wing (i.e. nationalist) politics, must be viewed as a big challenge to the churches to avoid blind support of the 'volk'.

The sixth reason implies that in all circumstances it is of the utmost importance to be aware of the influence, effect and dangers of any ideology (for example nationalism, ethnocentrism, imperialism) which is destructive and devastating in character. We find this trend even in Israel in the days of Christ: After his crucifixion the two men of Emmaus said to Him that they had hoped that He would be the one who was going to set Israel free (Luke 24:21). After his resurrection and shortly before his ascension even his disciples asked Him whether He would give the Kingdom back to Israel (Acts 1:6). This danger of an absolutized nationalism

19 See also articles in Beeld 23 January 2017:2. Once he came into power, Nelson Mandela followed a far more peaceful and reconciliatory approach (see Cruywagen 2016). See also the (critical) declaration of the South African Council of Churches in Benoni, June 6-8, 2017. 
does not only impact on Israel (even today), but on every nation on earth. ${ }^{20}$ Not our national kingdoms are important but the everlasting and universal kingdom of God, which includes the whole of creation. The church is a servant not of the 'volk' but of God and the kingdom of God.

\section{Concluding remarks}

We have travelled a long road of church failures as far as the relation between church and 'volk' is concerned. Why could the message of the Reformation on ecclesiology not prevent the identification of church and 'volk' and the disastrous consequences that followed upon this identification? Why could the Reformation not prevent the disintegration and disunity of the Protestant and Reformed churches as well as the development of 'volkskerke', which made an identification very easy?

It is very difficult to answer this question satisfactorily, as we have seen, and many factors played a lesser or greater role in this instance. A conclusive remark should be that the ecclesiology of the Reformation should be revisited in this regard and a far greater emphasis should be placed on the confession of unity of the church as the body of Christ. And on the message of reconciliation which should also reflect in societal matters.

In his prayer John 17:21 Christ prayed for the unity of the church, which means that his followers also should never neglect constant prayer for the unity of the church and the guidance of the Holy Spirit, for it is only the Spirit of truth who will lead the church of Christ into all the truth (John 16:13) - also the truth of a true and united church as well as a free and just society which may be a small sign of the coming kingdom of God. 


\section{Bibliography 2}

Améry, J. 1980. At the mind's limits: Contemplations by a survivor on Auschwitz and its realities. Bloomington IN.: Indiana University Press.

Allen, J. 2006. Rabble-Rouser for Peace. The Authorized Biography of Desmond Tutu. Johannesburg: Random House.

Bavinck, H. 1928. Gereformeerde Dogmatiek I. Kampen: Kok.

Banze, M.N. 2015, The Spirit of God and the spirits of Africa: a dogmatological study from the vantage point of pneumatology, PhD thesis, Faculty of Theology, North-West University, Potchefstroom.

Bergh, J.S. 2017. Paul Kruger. Toesprake en Korrespondensie van 1881-1900, Pretoria: Protea.

Brits, E., 2016. Emily Hobhouse. Beloved Traitor, transl. L. Dietrich. Cape Town: Tafelberg.

Bosch, D.J. 1991. Transforming Missions. Paradigm Shifts in Theology of Mission. New York: Orbis Books.

Botha, N. 2017. 'Zuma se gevaarlike teologie', Beeld, 28 Januarie, p. 18.

Bossenbroek, M. 2012. Die Boereoorlog, vert. A-M Mischke. Amsterdam: Athenaeum-Polak \& Van Gennep.

Busch, E., 1976. Karl Barths Lebenslauf: Nach seinen Briefen und autobiographischen Texten. München: Kaiser.

Calvijn, Johannes, 1559, Institutie of Onderwijzing in de Christelijke Godsdienst, vert. A. Sizoo, 1956. Delft: Naamloze Vennootschap WD Meinema.

Coetzee, J.C. 1965. Good en Godsvolk in die Nuwe Testament. Potchefstroom: Pro Rege.

Cruywagen, D. 2016 The Spiritual Mandela. Faith and Religion in the Life of South Africa's Great Statesman. Cape Town: Zebra Press.

D'Assonville, V.E. 1977. Totius - Profeet van die Mooirivier: 'n Lewenskets van prof. dr. J.D. du Toit. Kaapstad: Tafelberg.

De Gruchy, J.W. 1998. 'Recovering ecumenical vision and commitment in a post-ecumenical era', Journal of Theology for Southern Africa, November, 1-12.

Du Plessis, P.G. 2008. Fees van die ongenooides Kaapstad: Tafelberg.

Du Toit, J.D. 1941, Die Bybel is die Woord van God. Stellenbosch: Pro Ecclesia.

Du Toit, J.D. 1977. Totius: Versamelde Werke 7: Die staat, maatskappy, taal en kultuur. Kaapstad: Tafelberg. Duvenage, S.C.W. 1981. Kerk, volk en jeug. Deel I: Die verhouding van kerk tot volk, Zaandijk: J Heijnis.

Ericksen, R.P.1986. Theologians under Hitler: New Haven: Yale University Press.

Forstman, J. 1992. Christian Faith in Dark Times: Theological Conflicts in the Shadow of Hitler. Louisville KY.: Westminster/John Knox Press.

Giliomee, H. 2016/ Hermann Giliomee: Historikus. 'n Outobiografie Kaapstad: Tafelberg,

Giliomee, H. \& Mbenga, B. (reds.) 2007. Nuwe Geskiedenis van Suid-Afrika. Kaapstad: Tafelberg.

Jansen, H. 1983. Christelijke theologie na Auschwitz. Deel 1 Theologische en kerkelijke wortels van het antisemitisme. 's-Gravenhage: Boekencentrum.

Janson, M. 1967. Kerk en ideologie. Toe 'n volk so byna deur 'n teologie vernietig is. "Die Evangelis", Potchefstroom.

Joubert, S. 2012. Ontsluit die Nuwe Testament. Omvattende Bybelreise vir 'n beter verstaan van die Skrif.

21 After completion of this article (November 2017) I received through e-mail an advertisement of the book Apartheid. Britain's Bastard Child, written by Héléne Opperman Lewis (Publisher: Reach Uitgewers). Supplementary information states that the book offers a unique view into the minds of Afrikaners and investigates how the humiliation and atrocities of the wars impacted their collected psyche. This psychological approach to history - known as psychohistory uncovers the layers of humiliation and trauma that the Afrikaner experienced in the past. It follows the Afrikaner through the years - from 1795 to 1948. Lewis explains the reason for her book as follows: "My aim is not to justify apartheid, but to shed light on the historical events and psychological factors which informed its origination. It is not a history, but rather a case study steeped in history." She continues by saying: "Fifteen years of research for this book has yielded evidence of at least 200 years of prejudice against Afrikaners..." It is a pity that I could not profit from the insights which were developed in this book. 
Vereeniging: CUM.

König, A. 2014. Die Groot Geloofskommentaar.Vereeniging: CUM.

König, A. 2017. Paulus. Die indringer-apostel wat die evangelie gered het. Vereeniging: CUM.

Malan, C.J. 1981. Die Nadere Reformasie, Potchefstroom: PUCHO/IBC.

Malan, D.F. 1959. Afrikaner-Volkseenheid en my ervarings op die pad daarheen. Kaapstad: Nasionale Boekhandel.

Moltmann, J. 2008. A Broad Place: An Autobiography, trans. M. Kohl. Minneapolis: Fortress Press.

Moltmann, J. 2012. Ethics of hope, trans. M. Kohl. London: SCM Press.

Neuer, W. 1988. Adolf Schlatter. Wuppertal: R. Brockhaus Verlag.

Overduin, J. n.d. Hemel en hel in Dachau. Kampen: Kok.

Packenham, T. 1999. Die Boere-oorlog, vert. L. Rousseau Pretoria: Protea.

Pretorius, F. 1998. Die Anglo-Boereoorlog 1899-1902. Kaapstad: Struik.

Scholtz, L. 2016. Kruispaaie. Afrikanerkeuses in die 19de en 20ste eeu. Pretoria: Kraal Uitgewers.

Schulze, L.F. 1978. Geloof deur die eeue. Pretoria: NG Kerkboekhandel.

Smurthwaite, D. 1999. Hamlyn History. The Boer War. London: Hamlyn.

Thom, H.B. 1980. D.F. Malan. Kaapstad: Tafelberg.

Van den Brink, G. \& Van der Kooi, C. 2013. Christelijke Dogmatiek. Een Inleiding. Boekencentrum: Zoetermeer.

Van Itterzon, G.P. \& Nauta, D. (reds.) 1967. Geschiedenis der kerk XXIII \& XXIV. Kampen: Kok.

Van der Walt, B.J. (ed.) 1987. 'n Reformatoriese Kommentaar op die Kairos-Dokument. Potchefstroom: IRS.

Van der Walt, S.J. 1989. Die Roeping van die Kerk ten opsigte van etiese vraagstukke in die samelewing met toespitsing op uitsprake van die sinodes van Die Gereformeerde Kerke in Suid-Afrika, ThD proefskrif: Fakulteit Teologie, PUCHO.

Van der Watt, J. \& Tolmie, F. 2014. Ontdek die Boodskap van die Nuwe Testament. Vereeniging: CUM.

Van Wyk, J.H. 1985. Man van die derde weg. W.J. Snyman as teoloog. Potchefstroom: PUCHO.

Van Wyk, J.H. 1989. Die Woord is waardevol. 'n Dogmatiese besinning oor die reformatoriese Skrifbeskouing. Potchefstroom: PUCHO.

Van Wyk, J.H. 1991. Moraliteit en Verantwoordelikheid. Opstelle oor Politieke Etiek. Potchefstroom: PTP.

Van Wyk, J.H. 1993. Homo Dei. 'n Prinsipiële besinning oor enkele mensbeskouings, waaronder dié van Calvyn, In die Skriflig, Supplementum 1.

Van Wyk, J.H. 1998. Etiek in eenvoud. Gesprekke oor morele vraagstukke, Potchefstroom: PTP.

Van Wyk, J.H. 2001. Etiek en eksistensie - in koninkryksperspektief. Potchefstroom: PTP.

Van Wyk, J.H. 2015. Teologie van die koninkryk. Studies in dogmatiek en etiek. Potchefstroom: Vanwyk.

Verster, P. 2017 'n Sendingwetenskaplike ondersoek na die betekenis van eiesoortige kultuur', Tydskrif vir Geesteswetenskappe, 57(3),772-783.

Vorster, J.M. 2008. The challenge of contemporary religious fundamentalism. Pretoria: Unisa Press.

Vorster, J.M. 2014. Christelike etiek in 'n sekulariserende samelewing, Durbanville: Aosis. Doi: https://doi. org/10.4102/aosis.ceiss.2014.01.05

Wessels, E. \& Raath, A.W.G. (eds.) 2012. Onthou! Kronieke van vroue- en kinderlyding, 1899-1902. Pretoria: Kraal.

Wind, R. 1991. A spoke in the wheel: The life of Dietrich Bonhoeffer. London: SCM Press.

Winterbach, I. 2002. Niggie. Kaapstad: Human \& Rousseau. 